\title{
Development of novel polymorphic nuclear and chloroplast microsatellite markers in coast redwood (Sequoia sempervirens)
}

\begin{tabular}{|c|c|}
\hline Journal: & Plant Genetic Resources \\
\hline Manuscript ID & Draft \\
\hline Manuscript Type: & Short Communication \\
\hline Date Submitted by the Author: & $\mathrm{n} / \mathrm{a}$ \\
\hline Complete List of Authors: & $\begin{array}{l}\text { Breidenbach, Natalie; Georg-August University of Göttingen, Department } \\
\text { of Forest Genetics and Forest Tree Breeding } \\
\text { Gailing, Oliver ; Georg-August University of Göttingen, Department of } \\
\text { Forest Genetics and Forest Tree Breeding } \\
\text { Krutovsky, Konstantin; Georg-August University of Göttingen, Department } \\
\text { of Forest Genetics and Forest Tree Breeding; Vavilov Institute of General } \\
\text { Genetics, Russian Academy of Sciences, Laboratory of Population Genetics }\end{array}$ \\
\hline Keywords: & cpSSR, EST-SSR, hexaploid \\
\hline Abstract: & $\begin{array}{l}\text { The range-wide genetic structure of the highly productive and valuable } \\
\text { timber species Sequoia sempervirens (D. Don) Endl. is still insufficiently } \\
\text { studied, although published data based on different genetic markers } \\
\text { (nuclear and chloroplast microsatellites, AFLP, RFLP and isozymes) } \\
\text { demonstrated relatively low population structure. However, more genetic } \\
\text { markers are needed to increase the efficiency of population genetic studies } \\
\text { in coast redwood. Therefore, we developed seven nuclear and five } \\
\text { chloroplast microsatellite or simple sequence repeat (SSR) markers based } \\
\text { on expressed sequence tags (ESTs) and complete chloroplast genome } \\
\text { sequence, respectively. All selected markers were tested in a range-wide } \\
\text { sample representing trees from } 16 \text { locations. They are highly polymorphic } \\
\text { microsatellite loci with number of alleles ranging from } 3 \text { to } 17 \text {, and number } \\
\text { of effective alleles from } 1.1 \text { to } 2.48 \text {. Coast redwood is a hexaploid species, } \\
\text { and its chloroplasts are paternally inherited. Therefore, the chloroplast SSR } \\
\text { (cpSSR) markers are especially useful for this species, because their } \\
\text { genotyping is not affected by nuclear genome ploidy. Moreover, they } \\
\text { showed high gene diversity for each locus within and across all populations } \\
\text { and can be used to study range-wide population genetic structure, pollen } \\
\text { based gene flow and long distance gene transfer. Coast redwood can } \\
\text { propagate clonally, and nuclear polymorphic EST-SSRs can be used for } \\
\text { clonal identification. They are linked with expressed genes and their } \\
\text { variation can reflect variation in genes under selection, including those that } \\
\text { could be potentially important for local adaptation of coast redwood } \\
\text { considering the threat of climate change. }\end{array}$ \\
\hline
\end{tabular}

\section{SCHOLARONE ${ }^{\mathrm{m}}$}

Manuscripts 


\title{
Short Communication
}

\section{Development of novel polymorphic nuclear and chloroplast} microsatellite markers in coast redwood (Sequoia sempervirens)

\author{
Natalie Breidenbach ${ }^{1}$, Oliver Gailing ${ }^{1}$, Konstantin V. Krutovsky ${ }^{1,2,3,4^{*}}$
}

\section{${ }^{1}$ Department of Forest Genetics and Forest Tree Breeding, Georg-August University of} Göttingen, Büsgenweg 2, Göttingen 37077, Germany, ${ }^{2}$ Laboratory of Population Genetics, Vavilov Institute of General Genetics, Russian Academy of Sciences, Moscow 119991, Gubkina Str. 3, Russian Federation, ${ }^{3}$ Laboratory of Forest Genomics, Genome Research and Education Center, Institute of Fundamental Biology and Biotechnology, Siberian Federal University, Akademgorodok 50a/2, Krasnoyarsk 660036, Russian Federation and ${ }^{4}$ Department of Ecosystem Sciences and Management, Texas A\&M University, College Station, Texas 77843-2138, USA

*Corresponding author. Email: konstantin.krutovsky@forst.uni-goettingen.de ORCID: http://orcid.org/0000-0002-8819-7084

\section{Abstract}

The range-wide genetic structure of the highly productive and valuable timber species Sequoia sempervirens (D. Don) Endl. is still insufficiently studied, although published data based on different genetic markers (nuclear and chloroplast microsatellites, AFLP, RFLP and isozymes) demonstrated relatively low population structure. However, more genetic markers are needed to increase the efficiency of population genetic studies in coast redwood. Therefore, we developed seven nuclear and five chloroplast microsatellite or simple sequence repeat (SSR) markers based on expressed sequence tags (ESTs) and complete chloroplast genome sequence, respectively. All selected markers were tested in a range-wide sample representing trees from 16 locations. They are highly polymorphic microsatellite loci with number of alleles ranging from 3 to 17, and number of effective alleles from 1.1 to 2.48. Coast redwood is a hexaploid species, and its chloroplasts are paternally inherited. Therefore, the chloroplast SSR (CPSSR) markers are especially useful for this species, because their genotyping is not affected by nuclear genome ploidy. Moreover, 
they showed high gene diversity for each locus within and across all populations and can be used to study range-wide population genetic structure, pollen based gene flow and long distance gene transfer. Coast redwood can propagate clonally, and nuclear polymorphic ESTSSRs can be used for clonal identification. They are linked with expressed genes and their variation can reflect variation in genes under selection, including those that could be potentially important for local adaptation of coast redwood considering the threat of climate change.

Keywords: coast redwood, Sequoia sempervirens, cPSSR, EST-SSR, microsatellites

\section{Introduction}

The natural distribution of coast redwood (Sequoia sempervirens (D. Don) Endl.) extends along the pacific coast of northern California to southern Oregon (Roy, 1966). It is an important timber species, but there are only a few studies concerning its range-wide genetic variation and differentiation (Hall and Langenheim, 1987; Brinegar, 2011; Douhovnikoff and Dodd, 2011). All these studies found relatively low genetic differentiation among analysed populations. On the contrary, fine scale and individual clone differentiations were highly significant (Rogers, 2000; Douhovnikoff et al., 2004; Ibañez et al., 2009; Narayan et al., 2015). It seems that more genetic markers are needed to increase the efficiency of population genetic studies in coast redwood. We used publicly available expressed sequence tag (EST) and complete chloroplast genome sequence data to develop new microsatellite or simple sequence repeat (SSR) markers for coast redwood.

\section{Experimental}

Needles from 309 trees in 16 locations were collected within the natural distribution range of coast redwood in central and northern California (Online Supplementary 1). The collected needles were dried on silica gel. DNA was extracted from two needles per sample using the DNeasy 96 Plant Kit (Qiagen, Hilden, Germany) following the manufacturer's instructions. The extracted DNA was diluted in $\mathrm{ddH}_{2} \mathrm{O} 1: 10$ for PCR and stored at $-20^{\circ} \mathrm{C}$.

Possible microsatellite motifs were found by search for dinucleotide and trinucleotide SSR-motifs for EST-SSRs in the transcriptome data of Scott et al. (2016) and for all SSR-motifs 
in the complete chloroplast genome sequence (NCBI GenBank accession number NC_030372.1) using the SciRoko program (Kofler et al., 2007). Primer3 0.4.0 (Untergasser et al., 2012) was used to design the PCR primer pairs and oligoCalc (Kibbe, 2007) to check for possible dimers and hairpins. In total, 57 primer pairs for different SSR-motifs were tested. The EST-SSR forward primers were labelled with either Hex or 6-FAM (Error! Reference source not found.). Following Schuelke (2000), PCRs for cpSSRs were performed with 5' tailed 6-FAM dye-labelled M13 (5'-CACGACGTTGTAAACGAC-3') forward and PIG-tailed (5'GTTTCTT-3') reverse primers (Kubisiak et al., 2013).

For all 12 primer pairs the following touch-down PCR program was used. First denaturation at $94{ }^{\circ} \mathrm{C}$ for $15 \mathrm{~min}$, followed by 17 cycles with denaturation at $94{ }^{\circ} \mathrm{C}$ for $1 \mathrm{~min}$, annealing at $67^{\circ} \mathrm{C}$ for $1 \mathrm{~min}$ and elongation at $72{ }^{\circ} \mathrm{C}$ for $1 \mathrm{~min}$, after each cycle the annealing temperature was decreased by $1^{\circ} \mathrm{C}$, followed by 18 cycles with the annealing temperature at $50{ }^{\circ} \mathrm{C}$ for $1 \mathrm{~min}$.

PCR products were separated using the ABI genetic analyser 3130xI with GENSCAN ROX 500 as the internal size standard. GeneMapper 4.1. (Applied Biosystems) was used for visualization of the PCR products.

We finally selected seven EST-SSRs that were genotyped following the procedure for selecting reliable and consistently reproducible alleles suggested in Pfeiffer et al. (2011). In total, 270 and 297 samples were genotyped for the EST-SSR and the cpSSR markers, respectively. For each locus number of alleles $\left(N_{a}\right)$, number of effective alleles $\left(N_{e}\right)$, Shannon Index $(I)$, Nei's total gene diversity $\left(H_{t}\right)$ and Nei's within population gene diversity $\left(H_{s}\right)$ was calculated.

For the EST-SSR markers $N_{a}$ and I were calculated using the R-package "polysat" for polyploid species (Clark et al., 2011), and the converted binary input file was used to calculate $H_{t}$ and $H_{s}$ with the PopGene (Yeh et al., 1997) and $N_{e}$ with the GenAlEx (Peakall and Smouse, 2006; Peakall and Smouse, 2012) programs. The cpSSRs were analysed using GenAlEx $\left(N_{a}, N_{e}\right.$ and $\left.I\right)$ and the R-package "hierfstat" ( $H_{t}$ and $\left.H_{s}\right)$ (Goudet and Jombart, 2015).

\section{Discussion}

The program SciRoKo identified 76 microsatellites with dinucleotide motif, six with trinucleotide motif in ESTs, and six microsatellites with a dinucleotide motif in the chloroplast genome. From all EST-SSRs one with trinucleotide and six with dinucleotide 
motifs and among six cpSSRs five dinucleotide motifs were reliable and polymorphic, and thus were selected for further analysis (Error! Reference source not found.). The number of alleles ranged from 5 to 17 for EST-SSRs and from 3 to 10 for cpSSRs, number of effective alleles from 1.02 to 1.25 for EST-SSRs) and from 1.14 to 2.48 for cpSSRs), Shannon index from 0.21 to 2.19 for EST-SSR and from 0.19 to 0.97 for cpSSRs, gene diversity from 0.02 to 0.19 for EST-SSRs and from 0.10 to 0.65 for cpSSRs (Error! Reference source not found.). Due to the use of binary data to compute $H_{t}$ and $H_{s}$ for EST-SSRs, these parameters of gene diversity cannot be directly compared between EST-SSRs and cpSSRs (Nybom 2004).

As expected, EST-SSRs showed lower number of alleles than the published random nuclear SSRs (nSSRs) (Douhovnikoff and Dodd, 2011; Narayan et al., 2015), which was observed also earlier in other plants including conifers (e.g., Euyal et al., 2001; Rungis et al., 2004), supposedly because EST-SSRs are linked with expressed genes and can be under selection (Bouk and Vision, 2007).

The already published cpSSR Seq21 marker (Brinegar, 2011) showed more alleles and a higher Shannon Index than the new cpSSRs, except for ss60974. Chloroplasts in coast redwood are inherited paternally (Neale et al., 1989), and their markers are excellent tools to study pollen based gene flow and its contribution to population similarity. CpSSRs are usually highly polymorphic in conifer species (Vendramin et al., 1999; Viard, 2001; Bucci et al., 2007), and we found similar results in coast redwood.

Coast redwood is a hexaploid species (Stebbin, 1948), which complicates microsatellite genotyping (Douhovnikoff and Dodd, 2011; Narayan et al., 2015). The used microsatellite scoring routine based on the genotype verification using ramets of known clones (Pfeiffer et al., 2011), resulted in unambiguous and reliable multilocus genotypes. Due to the usually less polymorphic nature of EST-SSRs and the haploid nature of cpSSRs, both marker types might be less prone to genotyping errors than nSSRs, which frequently have many alleles of similar length (Hoffmann and Amos, 2005). Therefore, additional new EST-SSR and cpSSR might increase the resolution power of microsatellite markers to study population structure and local adaptation in coast redwoods. The highly polymorphic cpSSRs can be especially useful for genotyping of individuals and clone assignment based on the specific haplotypes.

\section{Acknowledgments}


We thank Alexandra Dolynska, Melanie Eckholdt and Babalola Jumoke for support during lab work. This project is funded by the „Fachagentur für nachhaltige Ressourcen (FNR) des Bundesministeriums für Ernährung und Landwirtschaft (BMEL)“.

\section{References}

Bouk A and Vision T (2007) The molecular ecologist's guide to expressed sequence tags. Molecular Ecology 16: 907-924.

Brinegar C (2011) Rangewide genetic variation in coast redwood populations at a chloroplast microsatellite locus. In R. B. Standiford, T. J. Weller, D. D. Piierto, and J. D. Stuart [eds.], Proceedings of the Coast Redwood Forests in a Changing California: A Symposium for Scientists and Managers, 241-249. USDA Forest Service General Technical Report PSWGTR-238. USDA Forest Service, Pacific Southwest Research Station, Albany, California, USA.

Bucci G, Gonzalez-Martinez SC, Le Provost G, Plomion C, Ribeiro MM, Sebastiani F, Alía R and Vendramin GG (2007) Range-wide phylogeography and gene zones in Pinus pinaster Ait. Revealed by chloroplast microsatellite markers. Molecular Ecology 16: 2137-2153.

Clark L and Jasieniuk M (2011) polysat: An R package for polyploid microsatellite analysis.

Molecular Ecology Resources 11: 562-566.

Douhovnikoff V, Cheng AM and Dodd RS (2004) Incidence, size and spatial structure of clones in second-growth stands of coast redwood, Sequoia sempervirens (Cupressaceae). American Journal of Botany 91: 1140-1146.

Douhovnikoff V and Dodd RS (2011) Lineage divergence in coast redwood (Sequoia sempervirens), detected by a new set of nuclear microsatellite loci. The American Midland Naturalist 165: 22-37.

Euyal I, Sorrells M, Baum M, Wolters P and Powell W (2001) Assessment of genotypic variation among cultivated durum wheat based on EST-SSRs and genomic SSRs. Euphytica 119: 39-43.

Goudet J and Jombart T (2015) hierfstat: Estimation and Tests of Hierarchical F-Statistics. Rpackage version 0.04-22. https://CRAN.R-project.org/package=hierfstat. 
Hall GD and Langenheim JH (1987) Geographic variation in leaf monoterpenes of Sequoia sempervirens. Biochemical Systematics and Ecology 15: 31-43.

Hoffmann JI and Amos W (2005) Microsatellite genotyping errors: detection approaches, common sources and consequences for paternal exclusion. Molecular Ecology 14: 599 612.

Ibañez MT, Caru M, Herrera MA, Gonzalez L, Martin LM, Miranda J and Navarro-Cerrillo RM (2009) Clones identification of Sequoia sempervirens (D.Don) Endl. In Chile by using PCRRAPDs technique. Journal of Zheijang University Science B 10: 112-119.

Kibbe WA (2007) OligoCalc: an online oligonucleotide properties calculator. Nucleic Acids Research 35: W43-W46.

Kofler R, Schlötterer C and Lelley T (2007) SciRoKo: a new tool for whole genome microsatellite search and investigation. Bioinformatics Application Notes 23: 1683-1685.

Kubisiak TL, Nelson CD, Staton ME, Zhebentyayeva T, Smith C, Olukolu BA, Fang G-C, Hebard FV, Anagnostakis S, Wheeler N, Sisco PH, Abbott AG and Sederoff RR (2013) A transcriptome-based genetic map of Chinese chestnut (Castanea mollissima) and identification of regions of segmental homology with peach (Prunus persica). Tree Genetics \& Genomes 9: 557-571.

Narayan L, Dodd RS and O'Hara KL (2015) A genotyping protocol for multiple tissue types from the polyploidy tree species Sequoia sempervirens (Cupressaceae). Applications in Plant Science 3: 1400110.

Neale D, Marshall K and Sederoff R (1989) Chloroplast and mitochondrial DNA are paternally inherited in Sequoia sempervirens D.Don.Endl. Proceedings of the National Academy of Science 86: 9347-9349.

Nybom H (2004) Comparison of different nuclear DNA markers for estimating intraspecific genetic diversity in plants. Molecular Ecology 13: 1143-1155.

Peakall, R. and Smouse P.E. (2006) GENALEX 6: genetic analysis in Excel. Population genetic software for teaching and research. Molecular Ecology Notes 6: 288-295.

Peakall, R. and Smouse P.E. (2012) GenAlEx 6.5: genetic analysis in Excel. Population genetic software for teaching and research-an update. Bioinformatics 28: 2537-2539. 
Pfeiffer T, Roschanski AM, Pannell JR, Korbecka G and Schnittler M (2011) Characterization of microsatellite loci and reliable genotyping in a polyploidy plant Mercurialis perennis (Euphorbiaceae). Journal of Heredity 102: 479-488.

Rogers DL (2000) Genotypic diversity and clone size in old-growth populations of coast redwood (Sequoia sempervirens). Canadian Journal of Botany 78: 1408-1419.

Rungis D, Bérubé Y, Zhang J, Ralph S, Ritland CE, Ellis BE, Douglas C, Bohlmann J and Ritland K (2004) Robust single sequence repeat markers for spruce (Picea spp.) from expressed sequence tags. Theoretical and Applied Genetics 109: 1283-1294.

Schuelke M (2000) An economic method for the fluorescent labelling of PCR fragments. Nature Biotechnology 18: 233-234.

Scott AD, Stenz NWM, Ingvarsson PK, Baum DA (2016) Whole genome duplication in coast redwood (Sequoia sempervirens) and its implications for explaining the rarity of polyploidy in conifers. New Phytologist 211: 186-193.

Stebbin GL Jr (1948) The chromosomes and relationships of Metasequoia and Sequoia. Science 108: 95-98.

Untergasser A, Cutcutache I, Koressaar T, Ye J, Faircloth BC, Remm M and Rozen SG (2012) Primer3-new capabilities and interfaces. Nucleic Acids Research 40: e115.

Vendramin GG, Degen B, Petit RJ, Anzidei M Madaghiele A and Ziegenhagen B (1999) High level of variation at Abies alba chloroplast microsatellite loci in Europe. Molecular Ecology 8: $1117-1126$.

Viard F, El-Kassaby YA and Ritland K (2001) Diversity and genetic structure in populations of Pseudotsuga menziesii (Pinaceae) at chloroplast microsatellite loci. Genome 44: 336-344.

Yeh FC, Yang R-C, Boyle T BJ (1997) POPGENE, the user-friendly shareware for population genetic analysis. Molecular Biology and Biotechnology Centre, University of Alberta, Canada. 


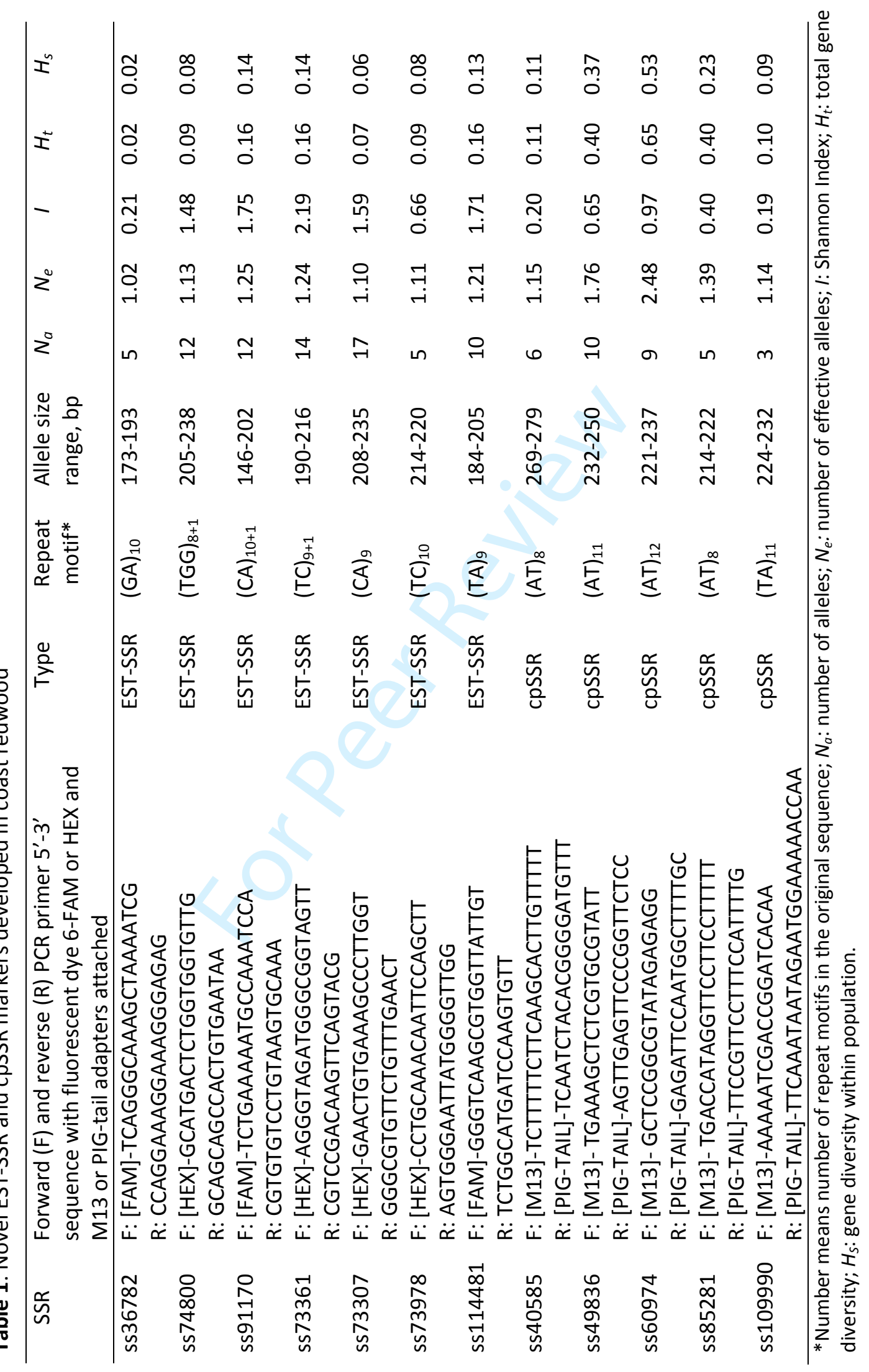

